http://dx.doi.org/10.11646/phytotaxa.126.1.4

\title{
Curcuma leonidii, a new species from southern Vietnam
}

\author{
J. LEONG-ŠKORNIČKOVÁ ${ }^{1} \&$ LUU HỒNG TRU'ÒNGG ${ }^{2}$ \\ ${ }^{I}$ The Herbarium, Singapore Botanic Gardens, 1 Cluny Road, Singapore 259569. E-mail: jana_skornickova@seznam.cz \\ ${ }^{2}$ Southern Institute of Ecology (Vietnam Academy of Science and Technology), 1 Mạc Đĩnh Chi Street, Hồ Chí Minh City, Vietnam
}

\begin{abstract}
Curcuma leonidii, a new species of Curcuma subg. Hitcheniopsis (Zingiberaceae) from southern Vietnam is described and illustrated here. Curcuma leonidii with flowers similar to some Stahlianthus-like species but inflorescences consisting of up to 8 green bracts and their arrangements conforming to usual 'classical' Curcuma-like species provides the much-awaited morphological link between the two genera, of which Stahlianthus have been, based on molecular results, recently proposed to be merged with Curcuma subg. Hitcheniopsis.
\end{abstract}

Key words: Bù Gia Mập National Park, Curcuma subgenus Hitcheniopsis, Stahlianthus

\section{Introduction}

Numerous ginger novelties, have recently been described (Dhetchuvi et al. 2011, Kumar et al. 2013), including a new genus (Leong-Škorničková et al. 2011) and numerous species from Indochina (e.g. LeongŠkorničková et al. 2010, 2011, Lý et al. 2010, Nguyen \& Leong-Škorničková 2012). As extensive explorations of Zingiberaceae for the Flora of Cambodia, Laos and Vietnam continue, numerous interesting ginger species have been collected, including the new Curcuma L. (1753) which we describe and illustrate below. It belongs to subgenus Hitcheniopsis Schuman (1904), because it lacks epigynous glands and anther spurs (Záveská et al. 2012).

This new species of Curcuma was first discovered in southern Vietnam in 2005, during the expedition by Prof. Leonid Averyanov \& his collaborators to Bình Phước Province, Bù Gia Mập National Park (HLF 5062, then identified as Kaempferia angustifolia Roscoe (1807)). The images of this collection have been confirmed to represent a new species by the first author who is revising Curcuma for the Flora of Cambodia, Laos and Vietnam. With no spirit or living flowering material at hand, the description of this new species was not pursued originally. The recent collections made by the second author were accompanied by material on spirit and photographs of flower dissections, which now allows us to formally describe this species.

Description based on living material Luu Hồng Truơng, Đinh Nhật Lâm \& Võ Huy Sang LUU 807 \& spirit material Lư Hồng Trưong, Đinh Nhật Lâm \& Võ Huy Sang LUU 897 \& LUU 898. Measurements derived from dried material are explicitly mentioned. Terminology follows Beentje (2012).

\section{Taxonomy}

Curcuma leonidii Škorničk. \& Lư

Similar to Curcuma harmandii Gagnep. (subg. Hitcheniopsis) in inflorescence consisting of green bracts with no obvious coma, but differs from it by having a more compact inflorescence (vs. more elongated in C. harmandii), white corolla lobes (vs. greenish), white oblanceolate-spathulate shape of the lateral staminodes (vs. greenish-white nearly linear) and white labellum with rich yellow well-defined median, the sides of the basal half of the median puberulent, patched with red, and nearly plain margin (vs. white labellum with yellow pubescent median bordered around with pink tinge, especially towards the apex, and crisped margin). 

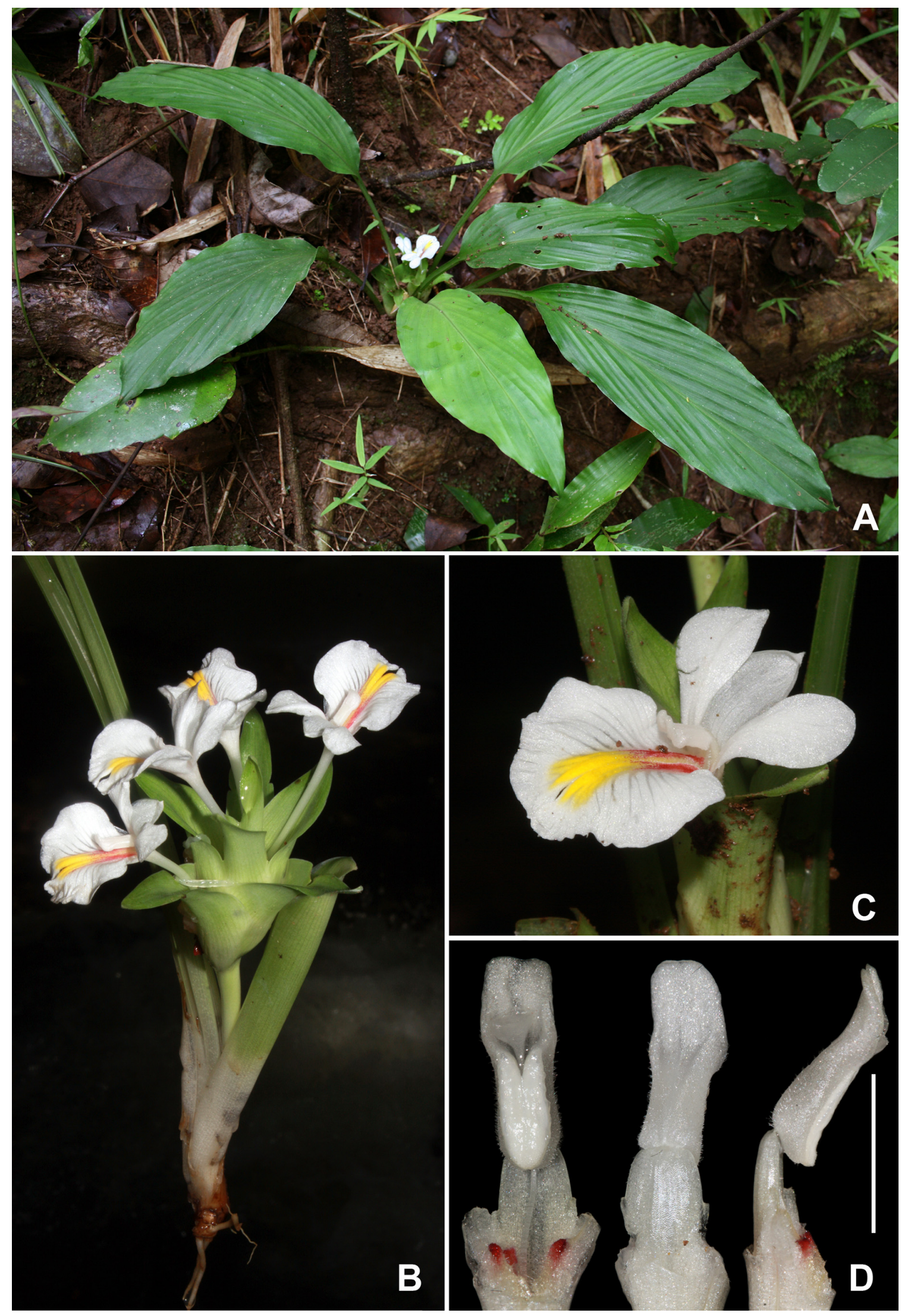

FIGURE 1. Curcuma leonidii A. Habit. B. Inflorescence. C. Flower. D. Anther (front, back and side views, scale bar 5 mm). Photo: Lư Hồng Trương. 
Type:-_VIETNAM. Bình Phước Province: Bù Gia Mập National Park, Đắc Ca stream, 8 May 2012, Luu Hồng Trưong, Đinh Nhật Lâm \& Võ Huy Sang LUU 807 (holotype SING!, isotypes SGN!, SING!). Figure 1.

Rhizomatous herbs to $30 \mathrm{~cm}$ tall. Rhizomes not branched, irregularly globose, ca $1 \times 1 \mathrm{~cm}$, externally light brown, internally light orange, root tubers present, placed $2-5 \mathrm{~cm}$ from rhizome. Pseudostems c. 3-5 cm (but fully opens up when the inflorescence emerges), composed of 1-2 leafless sheaths and 2-4 leaf sheaths; ligules $1-2 \mathrm{~mm}$, bilobed, hyaline, with a few stipitate hairs. Leafy shoots with $2-4$ leaves; petiole 3-8 $\mathrm{cm}$ (in dried specimens up to $7 \mathrm{~cm}$ ), green, canaliculate, externally puberulous; lamina elliptic-lanceolate, up to 22.0 $\times 6.5 \mathrm{~cm}$ (in dried specimens up to $18.5 \times 5.8 \mathrm{~cm}$ ), abaxially green, glabrous with sparse hairs along the midrib, adaxially lighter green, glabrous with sparse hairs along the midrib, base obtuse, slightly oblique, apex attenuate with uppermost tip densely hairy. Inflorescence central, peduncle $2-5 \mathrm{~cm}$, hidden between the leaf sheaths; spike 4-5 × c. 2-3 cm, coma absent. Bracts rhomboid, (1-)2-8(-10) per inflorescence, lower bracts ca 4.0-5.0 $\times 2.0-2.5 \mathrm{~cm}$ (in dried specimens up to $5.0 \times 1.2 \mathrm{~cm}$ ), upper bracts smaller, whitish-green, glabrous at base, green sparsely puberulous on both sides at apical half, connate to one another in lower 1/3-1/2, slightly reflexed at apex, all except the uppermost bract fertile. Cincinni with up to 7 flowers at the basal bracts, the number of flowers per cincinnus gradually decreasing upwards. Bracteoles one per flower, oblongoblanceolate, largest up to $15 \times 5 \mathrm{~mm}$ (at broadest point), others gradually smaller, hyaline, translucent-white, generally glabrous, but with sparse hairs at apex, along the keel. Flowers ca 5.5-6.0 cm, well exserted from bracts. Calyx 11-12 mm, with three obscure teeth, unilaterally split for 3-4 mm from apex, white, generally glabrous, with a short sparse hairs at teeth. Floral tube ca 3.5-3.8 cm long, narrowly cylindrical, slightly widening towards the apical part, externally pure white, mostly glabrous except apical funnel-shaped part being sparsely puberulous, internally white, hairy in apical part; dorsal corolla lobe obovate, ca 12-14 mm, 4 $\mathrm{mm}$ at base (6-7 $\mathrm{mm}$ at widest point), concave, glabrous, white, apex slightly cucullate with a small mucro (ca 0.5-1 mm), glabrous; lateral corolla lobes ca $10 \times 4 \mathrm{~mm}$, triangular-oblong, apex rounded, slightly concave, glabrous, white. Lateral staminodes oblanceolate-spathulate, up to $16 \mathrm{~mm}$ long, $5 \mathrm{~mm}$ at broadest point, pure white. Labellum ca $2.2 \times 2.0 \mathrm{~cm}$, orbicular, apex split ca $4 \mathrm{~mm}$, pure white on sides, with rich yellow, welldefined median, the sides of the basal half of the median patched with red. Stamen $10 \mathrm{~mm}$, pure white throughout; anther spurless, $7.5 \times 2.0 \mathrm{~mm}$, with glandular hairs on the sides of the connective; filament ca 3 $\mathrm{mm}$ long, ca $3 \mathrm{~mm}$ broad at base, ca $1.5 \mathrm{~mm}$ at the point of attachment to connective, glandular hairs sparsely present; anther thecae 3.5-4.0 mm, dehiscing along the entire length; anther crest present, $3-4 \times$ ca $3 \mathrm{~mm}$, glabrous. Stigma white, funnel-shaped, funnel flattened from front and back, ostiole front-top facing, ciliate. Epigynous glands absent. Ovary ovoid, $2.5-3 \times 2 \mathrm{~mm}$, trilocular, white, glabrous. Fruit (possibly not fully mature; described from a spirit material) obovoid, $1 \times 7 \mathrm{~mm}$, with persistent calyx, ca 11 seeds, seeds ovoid, 4-5 $\times 2 \mathrm{~mm}$, mid-brown, glabrous, with laciniate arils (translucent white?).

Etymology:-We dedicate this small but beautiful species to Prof. Leonid V. Averyanov, who first brought this species to our attention. Prof. Averyanov made exemplary contributions to the knowledge of Vietnamese Orchidaceae. With his main Vietnamese collaborators, Prof. Phan Kế Lộc and Dr. Nguyễn Tiến Hiệp, he also conducted multiple expeditions during past 20 years leading to great enhancement of general floristic and phytogeographic knowledge of Vietnam and adjacent areas of eastern Indochina (e.g. Averyanov et al. 2003).

Distribution \& IUCN preliminary assessment:-So far known only from several sites in Bù Gia Mập National Park, southern Vietnam. As this species has been reported so far only from less than five locations in Bù Gia Mập National Park (c. $260 \mathrm{~km}^{2}$ surrounded by a buffer zone of increasingly more populated areas and agricultural plantations), this species should be considered for the placement in the Endangered category, EN B1ab (i, ii).

Ecology and phenology:-The species is typically found in understory of lowland, broadleaved, evergreen forest, usually near streams, at around 350-400 m elevation. Flowering occurs between April to May, fruiting around July. 


\section{Discussion}

Recent molecular phylogeny of the genus Curcuma (Záveská et al. 2012) confirmed position of the genus Stahlianthus Kuntze (1891) within the genus Curcuma and most of the members of this genus are now being formally transferred (Leong-Škorničková et al., in prep.). Curcuma leonidii is an interesting find as it morphologically bridges the gap between Stahlianthus-like species characterised by inflorescence composed of two (or rarely three) fertile bracts and the 'classical' Curcuma-like species with few to many bracts per inflorescence. Flowers of C. leonidii are similar to those of other Stahlianthus species (Fig. 2 C, D), but the inflorescence with up to 8 green bracts and their arrangements conform to usual Curcuma species. Morphologically the closest species outside the Stahlianthus alliance is Curcuma harmandii Gagnep. (1907) (Fig. 2 A, B) that shares the character of an inflorescence composed of entirely green fertile bracts with no coma and similarly coloured flowers.
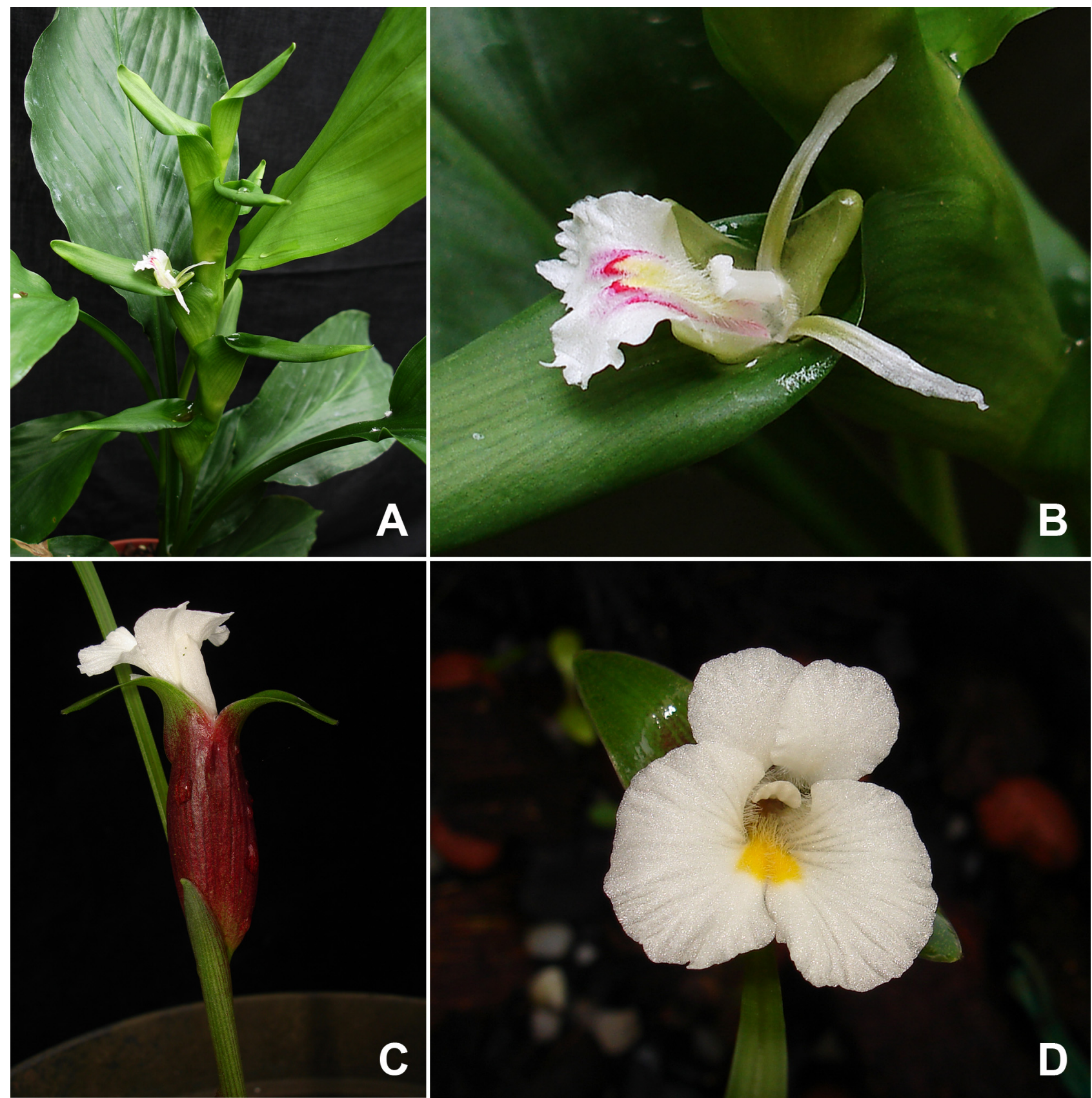

FIGURE 2. Curcuma harmandii. A. Inflorescence. B. Detail of flower. Stahlianthus sp. C. Inflorescence. D. Detail of flower. Photo: Jana Leong-Škorničková. 
Due to general similarity in shape of the inflorescence it is possible to mistake herbarium material of Curcuma leonidii with some species of subgenus Ecomata Škorničk. \& Š́da f. (in Záveská et al. 2012). The dissection of flowering material to confirm absence of epigynous glands is necessary, but rarely possible in dried material due to the generally poor state of flowers. This example, yet again, underscore the paramount importance of working with living flowering material, proper collection techniques including spirit collections and detailed field character documentation, including colour photographs, in order to make a progress in revising the family in Indochina and elsewhere.

The first collection was made by Averyanov et al. at Bù Gia Mập National Park (HLF 5062 as Kaempferia angustifolia), of which we only saw a picture, because the specimen was unable to locate at $\mathrm{HN}$ and was not present in the database at MO, and L. Averyanov confirmed it not to be present at LE (pers. comm.). The second observation of this species was at the same National Park by the second author (LHT) in 2007, with three subsequent collections he and his team made in 2012. The type collection from Đắc Ca stream was made from a single population on 8 May 2012 by Luu Hồng Truoong, Đinh Nhật Lâm \& Võ Huy Sang. Each plant was attached to a unique collection number: $L U U 807,808,809)$. The specimen with number $L U U 807$ was selected to be a holotype, because it has well-preserved inflorescence, and the remaining two specimens from this gathering, despite having different collection numbers, are thus to be treated as isotypes (ICN Arts 8.3., 9.4., McNeill et al. 2012). The other two collections were made by the same team from the same location, one on 7 May 2012 (collection numbers LUU 799, $800 \& 801$ ) and on 28 July 2012 (LUU 897 to 901). One more collection, $L U U$ 814, was made near Lưu Ly Waterfall, which lies about $1 \mathrm{~km}$ from Đắc Ca Stream. These as well as $H L F 5062$ (currently unlocated) are hereby designated as paratypes.

\section{Acknowledgements}

The authors thank the Asian Zingiberaceae Information Centre at Singapore Botanic Gardens and the Zingiberaceae Resource Centre at the Royal Botanic Garden Edinburgh (http://elmer.rbge.org.uk/ZRC/) for providing protologues and various Zingiberaceae related references. The first author thanks Prof. Leonid Averyanov for sharing extensive amounts of localised images, which, in conjunction with his specimens, are an invaluable resource to revise Vietnamese Zingiberales. The research of the first author is funded by the National Parks Board, Singapore and the Czech Science Foundation, GAČR (grant numbers 521/09/0202 and P506/10/0623), the second author is financially supported by the Vietnam Conservation Fund (decision No 31/QĐ-KL-VCF) and Bình Phước Provincial Department of Science and Technology (contract No 600/HĐ SKHCN). We thank Mr. Nguyễn Đại Phú, Mr. Vương Đức Hòa, Mr. Kiều Đình Tháp and staff of Bù Gia Mập National Park for their kind support during the field trips, and Mr. Đinh Nhật Lâm and Mr. Võ Huy Sang for their help during collection trips.

\section{References}

Averyanov, L., Loc, P.K., Hiep, N.T. \& Harder, D.K. (2003) Phytogeographic review of Vietnam and adjacent areas of eastern Indochina. Komarovia 3: 1-83.

Beentje, H. (2012) The Kew Plant Glossary, an illustrated dictionary of plant terms (revised edition). Kew Publishing, Royal Botanic Gardens Kew. 164 pp.

Dhetchuvi, J.-B., Wortley, A.H. \& Harris, D.J. (2011) A new species of Aframomum (Zingiberaceae) from Central Africa. Phytotaxa 28: 31-34.

Gagnepain, F. (1907) Zingibéracées, Marantacées et Musacées nouvelles de l'herbier du Muséum. (19note). Bulletin de la Société Botanique de France 54: 403-413.

Kumar, R., Mood, J., Singh, S.K. \& Sinha, B.K. (2013) A new species of Zingiber (Zingiberaceae) from Northeast India. Phytotaxa 77: 61-64. http://dx.doi.org/10.11646/phytotaxa.77.4.2

Kuntze, O. (1891) Revisio generum plantarum, vol. 2. Dulau \& Co. London. 
Leong-Škorničková, J., Tran, H.D., \& Newman, M.F. (2010) Curcuma vitellina (Zingiberaceae), a new species from Vietnam. Gardens' Bulletin Singapore 62: 111-117.

Leong-Škorničková, J., Lý, N.S., Poulsen, A.D., Tosh, J., Forrest, A. (2011) Newmania: A new ginger genus from central Vietnam. Taxon 60: 1386-1396.

Leong-Škorničková, J., Šída, O., Záveská, E. \& Marhold, K. (in prep.) Tidying up Curcuma L.: History of infrageneric classification, typication of supraspecific names and outstanding transfers based on latest phylogeny.

Linnaeus, C. (1753) Species plantarum. Impensis Laurentii Salvii, Stockholm.Lý, N.S., Hul, S. \& Leong-Š́korničková, J. (2010) Siliquamomum oreodoxa (Zingiberaceae): a new species from Southern Vietnam. Gardens'Bulletin Singapore 61: 359-367.

McNeill, J., Barrie, F.R., Buck, W.R., Demoulin, V., Greuter, W., Hawksworth, D.L., Herendeen, P.S., Knapp, S., Marhold, K., Prado, J., Prud'homme van Reine, W.F., Smith, G.F., Wiersema, J.H. \& Turland, N.J. (2012) International Code of Nomenclature for algae, fungi, and plants (Melbourne Code). Regnum Vegetabile 154. Koeltz Scientific Books, Königstein.

Nguyen, Q.B. \& Leong-Škorničková, J. (2012) Distichochlamys benenica (Zingiberaceae), a new species from Vietnam. Gardens' Bulletin Singapore 64: 195-200.

Roscoe, W. (1807) A new arrangement of plants of the monandrian class usually called Scitamineae. Transaction of the Linnean Socociety London 8: 330-357. http://dx.doi.org/10.1111/j.1096-3642.1807.tb00321.x

Schumann, K. (1904) Zingiberaceae. In: Engler, A. (ed.), Das Pflanzenreich, IV, vol. 46. Engelmann, Leipzig, pp. 1458.

Záveská, E., Fér, T., Šída, O., Krak, K., Marhold, K. \& Leong-Škorničková, J. (2012) Phylogeny of Curcuma (Zingiberaceae) based on plastid and nuclear sequences: Proposal of the new subgenus Ecomata. Taxon 61(4):747763 